\title{
Influence of girdling and zinc and boron application on growth, quality and leaf nutrient status of olive cv. Frontoio
}

\author{
Amit Jasrotia, Parshant Bakshi*, V. K. Wali, Bharat Bhushan and Deep Ji Bhat \\ Division of Fruit Science, Sher-e-Kashmir University of Agricultural Sciences and Technology of Jammu Faculty of \\ Agriculture, Main Campus, Chatha, Jammu-180009, India. \\ Received 8 October, 2013; Accepted 16 April, 2014
}

\begin{abstract}
The experiment was carried out during 2008 to 2009 and 2009 to 2010 with the aim to study the effect of girdling and foliar application of zinc and boron on growth, quality and leaf nutrient status of olive cv. Frontoio. The experiment was laid out in a randomized block design with seventeen treatments. Maximum shoot extension growth $(8.92 \mathrm{~cm})$ was observed with the spray of $0.6 \% \mathrm{ZnSO}_{4}$ in combination with $\mathbf{0 . 6 \%}$ boric acid. Maximum pulp:stone ratio of 2.57 and oil content of $25.62 \%$ was recorded with the foliar application of $0.6 \% \mathrm{ZnSO}_{4}$ in combination with $0.6 \%$ boric acid and $0.6 \% \mathrm{ZnSO}_{4}$ in combination with $0.4 \%$ boric acid, respectively. The highest leaf $\mathrm{K}(1.74 \%)$, Ca $(1.71 \%)$ and $\mathrm{Mg}(0.15 \%)$ contents were recorded with spray of $0.5 \% \mathrm{ZnSO}_{4}$ in combination with $0.4 \%$ boric acid, $0.5 \% \mathrm{ZnSO}_{4}$ in combination with $0.5 \%$ boric acid and $0.6 \% \mathrm{ZnSO}_{4}$ in combination with $0.6 \%$ boric acid, respectively. From this study, it is concluded that foliar application of zinc sulphate in combination with boric acid resulted in better growth, physical characteristics and oil content of olive fruits.
\end{abstract}

Key words: Olive, girdling, zinc, boron, leaf nutrient, oil content.

\section{INTRODUCTION}

Olive (Olea europea L.) is an evergreen tree, which requires chilling for its fruitfulness. Olive is grown for its fruits, used for oil extraction as its oil is a rich source of polyunsaturated fatty acids (PUFA). It possesses numerous biological properties and therefore occupies a pivotal position in human nutrition. Olive is an important crop in all countries situated in the Mediterranean region. The main producers of olive include Spain, Italy, Greece, Portugal, Turkey, etc. The total world production of olives was estimated at 20.58 million tonnes (FAO, 2012). Olive cultivation in India is still in its infancy and is restricted to the states of Jammu and Kashmir, Himachal Pradesh and Uttaranchal.

In olives, fruit weight and oil content are affected by the mineral status of leaves (Jordao and Lietao, 1990). The foliar feeding of micro-nutrients in different fruit crops, including olives, has assumed a significant position to enhance their growth, productivity and nutrient status. Nutrient sprays can influence qualitative and quantitative characteristics of olive, such as fruit size, weight, and fruit oil content. Rajaie et al. (2009) while studying the effect of zinc and boron interaction on growth and mineral

*Corresponding a uthor. E-ma il: bakshi_parshant@rediffma il.com, Tel: 9194191-01601 Author(s) a gree that this a rticle remain perma nently open access under the terms of the $\underline{\text { Creative Commons Attribution }}$ License 4.0 Intemational License 
composition of lemon seedlings (Citrus aurantifolia L.) observed that application of zinc and boron resulted in better plant growth and was associated with the highest uptake of $\mathrm{N}, \mathrm{P}, \mathrm{K}, \mathrm{Zn}, \mathrm{Fe}, \mathrm{Cu}$ and $\mathrm{Mn}$ under greenhouse conditions. Foliar application of zinc and boron in combination has been reported to elevate the leaf chlorophyll and $\mathrm{N}$ content, thus increasing shoot growth, in Persian walnut (Juglans regia) (Keshavarz et al., 2011). Therefore, the present experiment was undertaken to study the effect of girdling and zinc and boron application on growth, quality and leaf nutrient status of olive cv. Frontoio.

\section{MATERIALS AND METHODS}

\section{Study site}

The present investigation was conducted at the Division of Fruit Science, Faculty of Agriculture at Chatha, SKUAST-Jammu, India during 2008 to 2009 and 2009 to 2010 . The experimental site was situated in the intermediate zone at latitude $32^{\circ} 50^{\prime}$ North and longitude $74^{\circ} 55^{\prime}$ East at an elevation of $1100 \mathrm{~m}$ above mean sea level with an annual precipitation of about $910 \mathrm{~mm}$, mostly coinciding from February to June (about 80\%). The mean annual maximum and minimum temperatures are 21.72 and $12.57^{\circ} \mathrm{C}$, respectively.

Soil of the experimental field was clay loam with $\mathrm{pH}$ 6.4. The organic carbon content, available nitrogen, phosphorus and potassium contents of the soil were $0.87 \%, 283,73$ and $188 \mathrm{Kg} \mathrm{ha}$ ${ }^{1}$, respectively.

\section{Experimental setup}

The experiment was laid out in a randomized block design with seventeen treatments $\mathrm{T}_{1}$ : Control, $\mathrm{T}_{2}$ : Girdling, $\mathrm{T}_{3}: 0.4 \% \mathrm{ZnSO}_{4}, \mathrm{~T}_{4}$ : $0.5 \% \mathrm{ZnSO}_{4}, \mathrm{~T}_{5}: 0.6 \% \mathrm{ZnSO}_{4}, \mathrm{~T}_{6}: 0.4 \%$ Boric acid, $\mathrm{T}_{7}: 0.5 \%$ Boric acid, $\mathrm{T}_{8}: 0.6 \%$ Boric acid, $\mathrm{T}_{9}: 0.4 \% \mathrm{ZnSO}_{4}+0.4 \%$ Boric acid, $\mathrm{T}_{10}$ : $0.4 \% \mathrm{ZnSO}_{4}+0.5 \%$ Boric acid, $\mathrm{T}_{11}: 0.4 \% \mathrm{ZnSO}_{4}+0.6 \%$ Boric acid, $\mathrm{T}_{12}: 0.5 \% \mathrm{ZnSO}_{4}+0.4 \%$ Boric acid, $\mathrm{T}_{13}: 0.5 \% \mathrm{ZnSO}_{4}+0.5 \%$ Boric acid, $\mathrm{T}_{14}: 0.5 \% \mathrm{ZnSO}_{4}+0.6 \%$ Boric acid, $\mathrm{T}_{15}: 0.6 \% \mathrm{ZnSO}_{4}+0.4 \%$ Boric acid, $\mathrm{T}_{16}: 0.6 \% \mathrm{ZnSO}_{4}+0.5 \%$ Boric acid, and $\mathrm{T}_{17}: 0.6 \%$ $\mathrm{ZnSO}_{4}+0.6 \%$ Boric acid. Each treatment was replicated thrice with single tree as one replication (Figure 1). All the bearing branches of the trees were girdled by removing $10 \mathrm{~mm}$ wide rings of bark, one week before full bloom. Both the nutrients were sprayed in the first week of March and repeated 30 days after the first spray, during both years of investigation.

\section{Statistical analysis}

The data were subjected to statistical analysis according to the methodology proposed by Panse and Sukhatme (2000). Critical difference (C.D) at $5 \%$ level was used for finding the significant differences, if any, among the treatment means.

\section{Shoot extension growth}

For measuring shoot extension growth, twenty uniform and healthy shoots were randomly selected all over the tree canopy in all directions. The length of each shoot was measured at the beginning and end of growing season between the points of initiation of new growth to the extremity of the shoot tip and expressed in centimeters.

\section{Chlorophyll content}

Leaf chlorophyll content was estimated by the procedure reported by Arnon (1949) and the total chlorophyll content was calculated using the following equation:

Total chlorophyll $\left(\mathrm{mg}^{-1} \mathrm{~g}^{-1}\right)=20.2\left(\mathrm{~A}_{645}\right)+8.02\left(\mathrm{~A}_{663}\right) \times \frac{\mathrm{V}}{1000 \times \mathrm{W}}$

Where, $A_{645}=$ Absorbance at $645 \mathrm{~nm}, A_{663}=$ Absorbance at 663 $\mathrm{nm}, \mathrm{V}=$ volume of aliquot; $\mathrm{W}=$ weight of the leaf tissue $(\mathrm{g})$.

For the measurement of physical parameters of fruits, one hundred healthy fruits were randomly selected from each treatment.

\section{Fruit size}

Fruit size of fifteen randomly selected fruits from each replication was measured in centimeters by using a digital vernier caliper and was expressed as an average of length and diameter.

\section{Fruit weight}

Fruit weight was recorded on a top pan electrical balance with an accuracy of $\pm 0.5 \mathrm{~g}$ and expressed as mean fruit weight in grams.

\section{Fruit volume}

Fruit volume $\left(\mathrm{cm}^{3}\right)$ was estimated by the water displacement method using a graduated glass cylinder.

\section{Pulp: stone ratio}

For the estimation of pulp:stone ratio, fifteen fruits were randomly selected from each replication. The flesh of fruit was separated from the stone and the ratio between the weights of pulp and stone was worked out for all the treatments.

\section{Oil content}

Oil content of fruit pulp was estimated by the Soxhlet extraction method using hexane as a solvent (AOAC, 1980) and expressed in percentage on a fresh weight basis.

\section{Macro-nutrient}

For estimation of the macro-nutrient status of experimental trees, one hundred fully expanded leaves of each treatment along with petioles were sampled from the middle portion of the previous season's shoots situated all around the canopy of the tree as recommended by Chapman (1964). Cleaning, drying, grinding and storing of samples were carried out in accordance with the procedures outlined by Kenworthy (1964). For the estimation of $\mathrm{N}$, $0.5 \mathrm{~g}$ of plant material was digested in 15 to $20 \mathrm{ml}$ concentrated sulphuric acid in the presence of a digestion catalyst as described by Jackson (1973). The aliquot thus derived was used for the estimation of total $\mathrm{N}$ by micro Kjeldahl method (AOAC, 1980). The estimation of $\mathrm{P}, \mathrm{K}, \mathrm{Ca}$ and $\mathrm{Mg}$ digestion was done in a triacid 


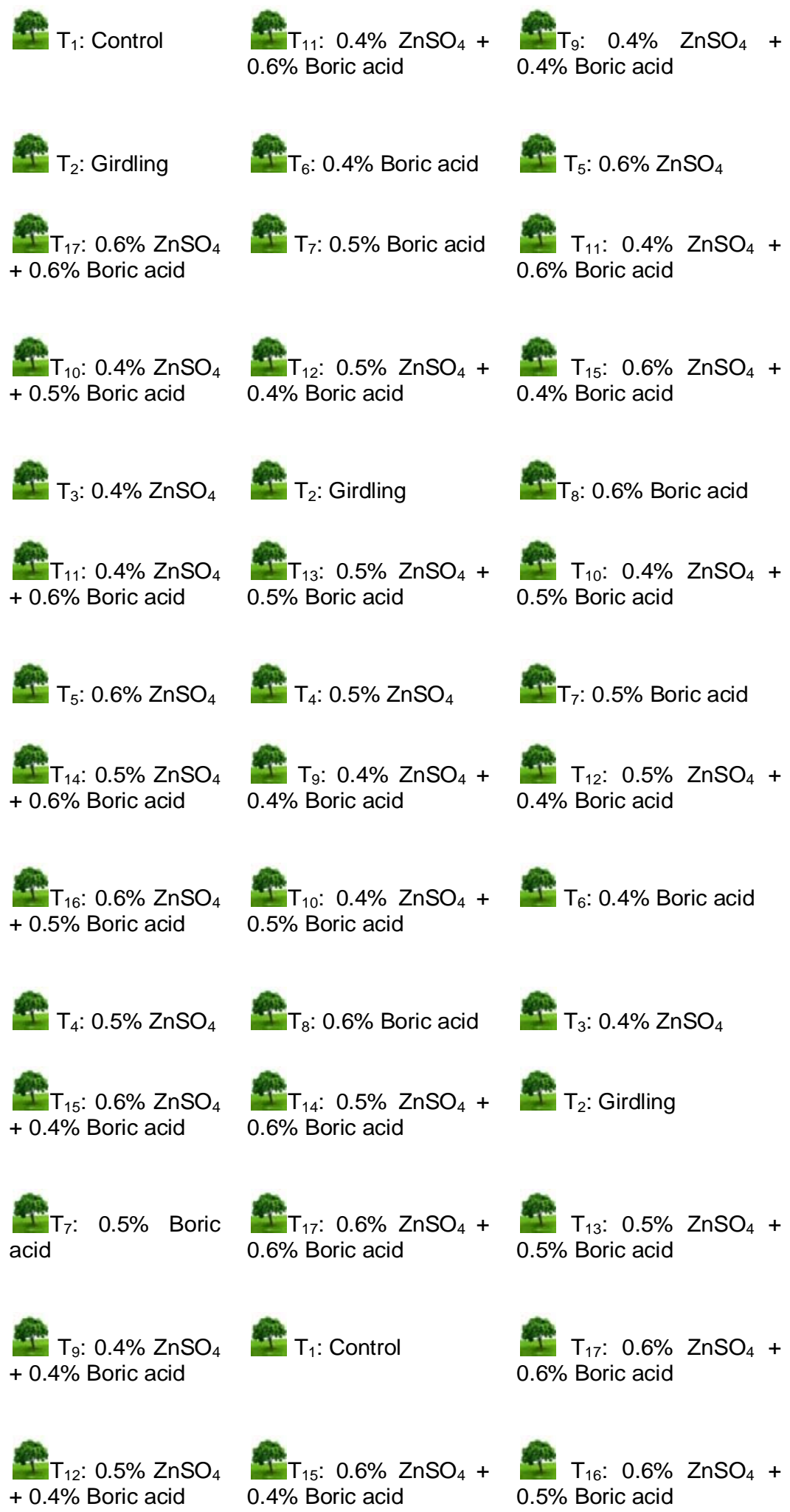

Figure 1. Layout of the experimental field.

mixture containing concentrated nitric acid, perchloric acid and sulphuric acid in the ratio of 10:4:1. All precautions, as suggested by Piper (1966), for wet digestion of leaf samples were taken. The volume of aliquot was made to $100 \mathrm{ml}$ and filtered through 
Table 1. Effects of girdling and zinc and boron application on shoot extension growth and chlorophyll content in olive cv. Frontoio.

\begin{tabular}{lcccccc}
\hline \multirow{2}{*}{ Treatment } & \multicolumn{3}{c}{ Shoot extension growth (cm) } & \multicolumn{3}{c}{ Chlorophyll content $\left(\mathbf{m g ~ g}^{\mathbf{- 1}}\right)$} \\
\cline { 2 - 7 } & $\mathbf{2 0 0 8 - 2 0 0 9}$ & $\mathbf{2 0 0 9 - 2 0 1 0}$ & Pooled & $\mathbf{2 0 0 8 - 2 0 0 9}$ & $\mathbf{2 0 0 9 - 2 0 1 0}$ & Pooled \\
\hline $\mathrm{T}_{1}$ & 6.10 & 6.63 & 6.37 & 1.10 & 1.02 & 1.06 \\
$\mathrm{~T}_{2}$ & 5.74 & 6.46 & 6.10 & 1.17 & 1.11 & 1.14 \\
$\mathrm{~T}_{3}$ & 6.65 & 6.64 & 6.65 & 1.25 & 1.18 & 1.21 \\
$\mathrm{~T}_{4}$ & 6.72 & 6.90 & 6.81 & 1.36 & 1.30 & 1.33 \\
$\mathrm{~T}_{5}$ & 7.10 & 6.82 & 6.96 & 1.42 & 1.37 & 1.40 \\
$\mathrm{~T}_{6}$ & 7.00 & 7.27 & 7.14 & 1.21 & 1.16 & 1.18 \\
$\mathrm{~T}_{7}$ & 7.24 & 7.30 & 7.27 & 1.32 & 1.27 & 1.29 \\
$\mathrm{~T}_{8}$ & 7.53 & 7.46 & 7.49 & 1.40 & 1.35 & 1.38 \\
$\mathrm{~T}_{9}$ & 7.88 & 7.62 & 7.75 & 1.28 & 1.21 & 1.24 \\
$\mathrm{~T}_{10}$ & 8.03 & 7.65 & 7.84 & 1.44 & 1.31 & 1.38 \\
$\mathrm{~T}_{11}$ & 8.22 & 7.81 & 8.02 & 1.53 & 1.47 & 1.50 \\
$\mathrm{~T}_{12}$ & 8.46 & 7.89 & 8.18 & 1.35 & 1.30 & 1.32 \\
$\mathrm{~T}_{13}$ & 9.22 & 8.15 & 8.69 & 1.48 & 1.42 & 1.45 \\
$\mathrm{~T}_{14}$ & 9.15 & 8.37 & 8.76 & 1.51 & 1.45 & 1.48 \\
$\mathrm{~T}_{15}$ & 9.40 & 8.26 & 8.83 & 1.31 & 1.25 & 1.28 \\
$\mathrm{~T}_{16}$ & 9.41 & 8.38 & 8.90 & 1.38 & 1.32 & 1.35 \\
$\mathrm{~T}_{17}$ & 9.39 & 8.44 & 8.92 & 1.43 & 1.38 & 1.40 \\
$\mathrm{C} . \mathrm{D}(0.05)$ & 1.11 & 1.35 & 0.86 & 0.11 & 0.13 & 0.08 \\
\hline
\end{tabular}

Whatman no.1 filter paper. Total $P$ was determined by the Vanadomolybdo phosphoric yellow colour method as described by Jackson (1973), while total $\mathrm{K}$ in the plant sample was estimated with the help of a Corning 410 digital Flame photometer. Calcium and Magnesium were determined on an Atomic Absorption Spectrophotometer.

\section{RESULTS AND DISCUSSION}

\section{Effects of girdling and micro-nutrients on shoot extension growth of olive}

The shoot extension growth was significantly influenced by girdling and micro-nutrient sprays of zinc and boron (Table 1). During 2008 to 2009, maximum shoot extension growth $(9.41 \mathrm{~cm})$ was recorded in trees sprayed with $0.6 \%$ zinc sulphate in combination with $0.5 \%$ boric acid which was statistically similar to shoot extension growth recorded in trees sprayed with $0.6 \%$ zinc sulphate in combination with $0.4 \%$ boric acid $(9.40$ $\mathrm{cm}), 0.6 \%$ zinc sulphate in combination with $0.6 \%$ boric acid $(9.39 \mathrm{~cm}), 0.5 \%$ zinc sulphate in combination with $0.5 \%$ boric acid $(9.22 \mathrm{~cm}), 0.5 \%$ zinc sulphate in combination with $0.6 \%$ boric acid $(9.15 \mathrm{~cm})$ and $0.5 \%$ zinc sulphate in combination with $0.4 \%$ boric acid $(8.46$ $\mathrm{cm})$ whereas, minimum shoot extension growth $(5.74 \mathrm{~cm})$ was recorded in girdled trees. However, during the second year (2009 to 2010), shoot extension growth ranged from 6.46 to $8.44 \mathrm{~cm}$, maximum shoot extension growth $(8.44 \mathrm{~cm})$ was recorded with $0.6 \%$ zinc sulphate in combination with $0.6 \%$ boric acid and least shoot extension growth $(6.46 \mathrm{~cm})$ was recorded in girdled trees. Pooled data showed maximum shoot extension $(8.92 \mathrm{~cm})$ in trees sprayed with $0.6 \%$ zinc sulphate in combination with $0.6 \%$ boric acid. The treatments viz., $0.6 \%$ zinc sulphate in combination with $0.5 \%$ boric acid, $0.6 \%$ zinc sulphate in combination with $0.4 \%$ boric acid, $0.5 \%$ zinc sulphate in combination with $0.6 \%$ boric acid, $0.5 \%$ zinc sulphate in combination with $0.5 \%$ boric acid and $0.5 \%$ zinc sulphate in combination with $0.4 \%$ boric acid were equally effective in registering shoot extension growth within the range of 8.18 to $8.90 \mathrm{~cm}$. Minimum shoot extension growth $(6.10 \mathrm{~cm})$ was registered in girdled trees. These findings are in accordance with the results obtained by Singh et al. (2009). They found that interactions of zinc, at higher levels and boron either at lower or higher concentration caused significant improvement in shoot length of mango cv. Dashehari. Decrease in shoot extension growth was recorded in olive trees with girdling as compared to untreated trees and is in consonance with the findings of Ungerer and Steyn (2009) and Choi et al. (2010) who also observed decreased shoot growth in persimmon with girdling as compared to untreated trees.

Effects of girdling and micro-nutrients on leaf chlorophyll content of olive

During 2008 to 2009, the highest leaf chlorophyll content 
Table 2. Effects of girdling and zinc and boron application on fruit size, fruit weight and fruit volume of olive cv. Frontoio

\begin{tabular}{lccccccccc}
\hline \multirow{2}{*}{ Treatment } & \multicolumn{3}{c}{ Fruit size $(\mathbf{c m})$} & \multicolumn{3}{c}{ Fruit weight $(\mathbf{g})$} & \multicolumn{3}{c}{ Fruit volume $\left(\mathbf{c m}^{3}\right)$} \\
\cline { 2 - 9 } & $\mathbf{2 0 0 8 - 2 0 0 9}$ & $\mathbf{2 0 0 9 - 2 0 1 0}$ & Pooled & $\mathbf{2 0 0 8 - 2 0 0 9}$ & $\mathbf{2 0 0 9 - 2 0 1 0}$ & Pooled & $\mathbf{2 0 0 8 - 2 0 0 9}$ & $\mathbf{2 0 0 9 - 2 0 1 0}$ & Pooled \\
\hline $\mathrm{T}_{1}$ & 1.27 & 1.29 & 1.28 & 1.13 & 1.18 & 1.15 & 1.31 & 1.33 & 1.32 \\
$\mathrm{~T}_{2}$ & 1.34 & 1.37 & 1.35 & 1.21 & 1.26 & 1.24 & 1.39 & 1.41 & 1.40 \\
$\mathrm{~T}_{3}$ & 1.31 & 1.33 & 1.32 & 1.16 & 1.22 & 1.19 & 1.35 & 1.37 & 1.36 \\
$\mathrm{~T}_{4}$ & 1.34 & 1.36 & 1.35 & 1.20 & 1.24 & 1.22 & 1.38 & 1.40 & 1.39 \\
$\mathrm{~T}_{5}$ & 1.35 & 1.39 & 1.37 & 1.22 & 1.27 & 1.24 & 1.40 & 1.41 & 1.41 \\
$\mathrm{~T}_{6}$ & 1.36 & 1.38 & 1.37 & 1.21 & 1.28 & 1.24 & 1.40 & 1.42 & 1.41 \\
$\mathrm{~T}_{7}$ & 1.43 & 1.40 & 1.42 & 1.27 & 1.30 & 1.28 & 1.44 & 1.46 & 1.45 \\
$\mathrm{~T}_{8}$ & 1.45 & 1.41 & 1.43 & 1.29 & 1.33 & 1.31 & 1.44 & 1.47 & 1.46 \\
$\mathrm{~T}_{9}$ & 1.44 & 1.44 & 1.44 & 1.27 & 1.36 & 1.32 & 1.46 & 1.49 & 1.48 \\
$\mathrm{~T}_{10}$ & 1.51 & 1.46 & 1.49 & 1.32 & 1.38 & 1.35 & 1.50 & 1.53 & 1.51 \\
$\mathrm{~T}_{11}$ & 1.55 & 1.43 & 1.49 & 1.34 & 1.41 & 1.38 & 1.49 & 1.54 & 1.52 \\
$\mathrm{~T}_{12}$ & 1.52 & 1.52 & 1.52 & 1.32 & 1.45 & 1.39 & 1.51 & 1.55 & 1.53 \\
$\mathrm{~T}_{13}$ & 1.60 & 1.54 & 1.57 & 1.39 & 1.50 & 1.45 & 1.59 & 1.63 & 1.61 \\
$\mathrm{~T}_{14}$ & 1.62 & 1.51 & 1.56 & 1.41 & 1.51 & 1.46 & 1.53 & 1.64 & 1.58 \\
$\mathrm{~T}_{15}$ & 1.56 & 1.54 & 1.55 & 1.35 & 1.48 & 1.42 & 1.55 & 1.59 & 1.57 \\
$\mathrm{~T}_{16}$ & 1.60 & 1.56 & 1.58 & 1.38 & 1.49 & 1.44 & 1.58 & 1.63 & 1.61 \\
$\mathrm{~T}_{17}$ & 1.62 & 1.57 & 1.59 & 1.39 & 1.51 & 1.45 & 1.59 & 1.62 & 1.60 \\
$\mathrm{C} . \mathrm{D}_{(0.05)}$ & 0.09 & 0.08 & 0.06 & 0.07 & 0.03 & 0.04 & 0.08 & 0.05 & 0.05 \\
\hline
\end{tabular}

$\left(1.53 \mathrm{mg} \mathrm{g}^{-1}\right.$-1) was observed in trees sprayed with $0.4 \%$ zinc sulphate in combination with $0.6 \%$ boric acid (Table 1) closely followed by trees sprayed with $0.5 \%$ zinc sulphate in combination with $0.6 \%$ boric acid, $0.5 \%$ zinc sulphate in combination with $0.5 \%$ boric acid, $0.4 \%$ zinc sulphate in combination with $0.5 \%$ boric acid and $0.6 \%$ zinc sulphate in combination with $0.6 \%$ boric acid registering values of $1.51,1.48,1.44$ and $1.43 \mathrm{mg} \mathrm{g}^{-1}-1$, respectively which were similar to each other, whereas the lowest leaf chlorophyll content $\left(1.10 \mathrm{mg} \mathrm{g}^{-1}{ }^{-1}\right)$ was obtained in untreated trees which was similar to the chlorophyll content recorded in girdled trees $\left(1.17 \mathrm{mg} \mathrm{g}^{-1}\right.$ $\left.{ }^{1}\right)$. The results from the second year also exhibited similar patterns as those observed in the first year of study. The leaf chlorophyll content ranged from 1.02 to $1.47 \mathrm{mg} \mathrm{g}^{-1}{ }^{-1}$ registering the highest chlorophyll content $\left(1.47 \mathrm{mg} \mathrm{g}^{-1}-1\right)$ in trees sprayed with $0.4 \%$ zinc sulphate in combination with $0.6 \%$ boric acid and the lowest leaf chlorophyll content $\left(1.02 \mathrm{mg} \mathrm{g}^{-1}{ }^{-1}\right)$ in untreated trees. The pooled data showed highest leaf chlorophyll content of $1.50 \mathrm{mg} \mathrm{g}^{-1}{ }^{-1}$ in the trees sprayed with $0.4 \%$ zinc sulphate in combination with $0.6 \%$ boric acid and was at par with the values found in trees sprayed with $0.5 \%$ zinc sulphate in combination with $0.6 \%$ boric acid $\left(1.48 \mathrm{mg} \mathrm{g}^{-1}\right.$ ${ }^{-1}$ ) and $0.5 \%$ zinc sulphate in combination with $0.5 \%$ boric acid $\left(1.45 \mathrm{mg} \mathrm{g}^{-1}{ }^{-1}\right)$. The lowest leaf chlorophyll content $\left(1.06 \mathrm{mg} \mathrm{g}^{-1}{ }^{-1}\right)$ was found in control. The findings in the present study are in line with the results obtained by Keshavarz et al. (2011) who recorded the highest chlorophyll index in Persian walnut with foliar application of $1050 \mathrm{mg} \mathrm{L}^{-1}$ zinc in combination with $174 \mathrm{mg} \mathrm{L}^{-1}$ boron.
The increase in leaf chlorophyll content with foliar sprays of zinc and boron can also be attributed to the fact that zinc is part of the carbonic anhydrous enzyme, present in all the photosynthetic tissues and it is required for chlorophyll biosynthesis (Ryugo, 1988). Nitrogen and magnesium are the main constituents of chlorophyll and nitrogen and magnesium status of leaves in trees is when is improved when sprayed with zinc and boron. However, in the present investigation girdling exerted no significant improvement in total leaf chlorophyll content. The lack of response to girdling in enhancing chlorophyll may be due to elevated starch level in the leaves of girdled shoots which inhibited the photosynthetic activity as reported by Proietti and Tombesi (1990) who also obtained similar results with girdling in olive cv. Leccino.

\section{Effects of girdling and micro-nutrients on physical parameters of olive}

All the physical parameters of fruits viz., fruit size, fruit weight and fruit volume were significantly increased with girdling as well as with foliar application of zinc sulphate and boric acid applied singly or in combination with each other (Table 2). Foliar spray of $0.5 \%$ zinc sulphate and $0.5 \%$ boric acid was found to be the best in enhancing all the physical parameters of olive fruits. A positive effect of girdling on fruit size and weight has been reported in grapes (Ahmad et al., 2005), persimmon (Choi et al., 2010) and peach (Chanana and Gill, 2006). A positive effect of zinc on fruit weight, size and volume, as the one 
Table 3. Effects of girdling and zinc and boron application on pulp:stone ratio and oil content of olive cv. Frontoio

\begin{tabular}{lcccrrr}
\hline \multirow{2}{*}{ Treatment } & \multicolumn{3}{c}{ Pulp:stone ratio } & \multicolumn{3}{c}{ Oil content (\%) } \\
\cline { 2 - 7 } & $\mathbf{2 0 0 8 - 2 0 0 9}$ & $\mathbf{2 0 0 9 - 2 0 1 0}$ & Pooled & $\mathbf{2 0 0 8 - 2 0 0 9}$ & $\mathbf{2 0 0 9 - 2 0 1 0}$ & Pooled \\
\hline $\mathrm{T}_{1}$ & 2.21 & 2.28 & 2.24 & $21.23(4.72)^{\star}$ & $20.68(4.66)$ & $20.96(4.69)$ \\
$\mathrm{T}_{2}$ & 2.28 & 2.36 & 2.32 & $22.20(4.82)$ & $22.03(4.80)$ & $22.12(4.81)$ \\
$\mathrm{T}_{3}$ & 2.25 & 2.66 & 2.45 & $21.86(4.78)$ & $21.84(4.78)$ & $21.85(4.78)$ \\
$\mathrm{T}_{4}$ & 2.28 & 2.36 & 2.32 & $22.28(4.82)$ & $22.57(4.85)$ & $22.42(4.84)$ \\
$\mathrm{T}_{5}$ & 2.30 & 2.38 & 2.34 & $22.62(4.86)$ & $22.92(4.89)$ & $22.77(4.88)$ \\
$\mathrm{T}_{6}$ & 2.30 & 2.39 & 2.34 & $23.11(4.91)$ & $23.41(4.94)$ & $23.26(4.93)$ \\
$\mathrm{T}_{7}$ & 2.33 & 2.42 & 2.37 & $23.10(4.91)$ & $23.40(4.94)$ & $23.25(4.92)$ \\
$\mathrm{T}_{8}$ & 2.35 & 2.43 & 2.39 & $23.19(4.92)$ & $23.49(4.95)$ & $23.34(4.93)$ \\
$\mathrm{T}_{9}$ & 2.36 & 2.46 & 2.41 & $24.02(5.00)$ & $24.30(5.03)$ & $24.16(5.02)$ \\
$\mathrm{T}_{10}$ & 2.39 & 2.50 & 2.44 & $24.01(5.00)$ & $24.28(5.03)$ & $24.15(5.01)$ \\
$\mathrm{T}_{11}$ & 2.39 & 2.50 & 2.44 & $23.66(4.97)$ & $24.25(5.02)$ & $23.96(4.99)$ \\
$\mathrm{T}_{12}$ & 2.44 & 2.56 & 2.50 & $25.25(5.12)$ & $25.53(5.15)$ & $25.39(5.14)$ \\
$\mathrm{T}_{13}$ & 2.49 & 2.60 & 2.55 & $25.26(5.12)$ & $25.50(5.15)$ & $25.38(5.13$ \\
$\mathrm{T}_{14}$ & 2.43 & 2.57 & 2.50 & $24.73(5.07)$ & $25.01(5.10)$ & $24.87(5.09)$ \\
$\mathrm{T}_{15}$ & 2.48 & 2.59 & 2.53 & $25.49(5.15)$ & $25.75(5.17)$ & $25.62(5.16)$ \\
$\mathrm{T}_{16}$ & 2.51 & 2.62 & 2.56 & $25.17(5.12)$ & $25.36(5.13)$ & $25.27(5.13)$ \\
$\mathrm{T}_{17}$ & 2.53 & 2.60 & 2.57 & $24.77(5.08)$ & $25.05(5.10)$ & $24.91(5.09)$ \\
$\mathrm{C} . \mathrm{D}(0.05)$ & 0.05 & NS & 0.12 & 0.07 & 0.07 & 0.05 \\
\hline
\end{tabular}

*Figures in the parentheses are transformed mean, NS: Non-significant.

the one obtained in the present investigation, has also been reported by Sharma et al. (2003) in kagzi lime and Singh et al. (2009) in mango as zinc is required to obtain good fruit size being the part of the carbonic anhydrous enzyme, present in the photosynthetic tissues and also required for chlorophyll biosynthesis (Ryugo, 1988). Similarly, boron application also resulted in an increase of fruit weight, size and volume.

The beneficial effect of boron on these parameters might be due to its role in cell division and cell elongation. Similar findings have been reported by Dutta (2004) in mango; Bybordi and Malakouti (2006) in almond and Yadav et al. (2010) in aonla. In the present investigation, the use of zinc and boron together might have acted synergistically thereby improving the physical parameters of olive fruit. Similar results have been obtained by Banik and Sen (1997) who observed a significant increase in fruit weight with the application of zinc in combination with boron in mango whereas, Tariq et al. (2007) also obtained maximum fruit size and fruit volume with foliar spray of zinc and boron in Blood Red cultivar of sweet orange.

\section{Effects of girdling and micro-nutrients on pulp: stone ratio of olive}

In the first year of study (Table 3), pulp:stone ratio reached to a maximum of 2.53 in trees sprayed with $0.6 \%$ zinc sulphate in combination with $0.6 \%$ boric acid closely followed by trees sprayed with $0.6 \%$ zinc sulphate in combination with $0.5 \%$ boric acid, $0.5 \%$ zinc sulphate in combination with $0.5 \%$ boric acid and $0.6 \%$ zinc sulphate in combination with $0.4 \%$ boric acid registering values of $2.51,2.49$ and 2.48 , respectively and were similar to each other.

The pulp: stone ratio during the second year of experimentation (2009 to 2010) ranged from 2.28 to 2.62 wherein, the maximum pulp:stone ratio (2.62) was recorded in trees sprayed with $0.6 \%$ zinc sulphate in combination with $0.5 \%$ boric acid and the minimum pulp: stone ratio (2.28) was obtained under untreated trees. The pooled data showed that maximum pulp:stone ratio (2.57) was observed in trees sprayed with $0.6 \%$ zinc sulphate in combination with $0.6 \%$ boric acid closely followed by trees sprayed with $0.6 \%$ zinc sulphate in combination with $0.5 \%$ boric acid, $0.5 \%$ zinc sulphate in combination with $0.5 \%$ boric acid, $0.6 \%$ zinc sulphate in combination with $0.4 \%$ boric acid, $0.5 \%$ zinc sulphate in combination with $0.6 \%$ boric acid, and $0.5 \%$ zinc sulphate in combination with $0.4 \%$ boric acid registering pulp:stone ratioss of $2.56,2.55,2.53,2.50$ and 2.50 , respectively, and were similar to each other. The minimum pulp: stone ratio (2.24) was found in untreated trees.

The results are in conformity with the findings of Hamdy et al. (2007) who obtained the highest pulp:stone ratio in mango CV. Hindy Bisinara with foliar application of a mixture containing citric acid (500 ppm), boric acid $(0.025 \%)$, chelated zinc $(0.05 \%)$ and magnesium sulphate $(0.25 \%)$. 
Table 4. Effects of girdling and zinc and boron application on total leaf $\mathrm{N}, \mathrm{P}, \mathrm{K}, \mathrm{Ca}$, and $\mathrm{Mg}$ in olive cv. Frontoio

\begin{tabular}{lccccc}
\hline \multirow{2}{*}{ Treatment } & $\mathrm{N}(\%)$ & $\mathbf{P}(\%)$ & $\mathrm{K}(\%)$ & $\mathrm{Ca}(\%)$ & $\mathrm{Mg}(\%)$ \\
\cline { 2 - 5 } & Pooled & Pooled & Pooled & Pooled & Pooled \\
\hline $\mathrm{T}_{1}$ & $1.58(1.60)^{*}$ & $0.216(1.10)$ & $1.57(1.60)$ & $1.50(1.58)$ & $0.135(1.06)$ \\
$\mathrm{T}_{2}$ & $1.62(1.62)$ & $0.227(1.11)$ & $1.67(1.63)$ & $1.62(1.62)$ & $0.141(1.07)$ \\
$\mathrm{T}_{3}$ & $1.61(1.62)$ & $0.225(1.11)$ & $1.67(1.63)$ & $1.60(1.61)$ & $0.145(1.07)$ \\
$\mathrm{T}_{4}$ & $1.64(1.63)$ & $0.226(1.11)$ & $1.67(1.63)$ & $1.63(1.62)$ & $0.148(1.07)$ \\
$\mathrm{T}_{5}$ & $1.62(1.62)$ & $0.226(1.11)$ & $1.69(1.64)$ & $1.65(1.63)$ & $0.149(1.07)$ \\
$\mathrm{T}_{6}$ & $1.62(1.62)$ & $0.224(1.11)$ & $1.69(1.64)$ & $1.66(1.63)$ & $0.146(1.07)$ \\
$\mathrm{T}_{7}$ & $1.60(1.61)$ & $0.224(1.11)$ & $1.70(1.64)$ & $1.65(1.63)$ & $0.148(1.07)$ \\
$\mathrm{T}_{8}$ & $1.61(1.62)$ & $0.219(1.10)$ & $1.72(1.65)$ & $1.65(1.63)$ & $0.147(1.07)$ \\
$\mathrm{T}_{9}$ & $1.61(1.62)$ & $0.226(1.11)$ & $1.72(1.65)$ & $1.67(1.63)$ & $0.146(1.07)$ \\
$\mathrm{T}_{10}$ & $1.68(1.64)$ & $0.224(1.11)$ & $1.72(1.65)$ & $1.68(1.64)$ & $0.148(1.07)$ \\
$\mathrm{T}_{11}$ & $1.68(1.64)$ & $0.219(1.10)$ & $1.73(1.65)$ & $1.66(1.63)$ & $0.150(1.07)$ \\
$\mathrm{T}_{12}$ & $1.68(1.64)$ & $0.220(1.10)$ & $1.74(1.65)$ & $1.71(1.64)$ & $0.147(1.07)$ \\
$\mathrm{T}_{13}$ & $1.61(1.61$ & $0.223(1.10)$ & $1.71(1.64)$ & $1.71(1.64)$ & $0.149(1.07)$ \\
$\mathrm{T}_{14}$ & $1.61(1.61)$ & $0.220(1.10)$ & $1.70(1.64)$ & $1.68(1.64)$ & $0.151(1.07)$ \\
$\mathrm{T}_{15}$ & $1.64(1.63)$ & $0.222(1.10)$ & $1.71(1.64)$ & $1.72(1.65)$ & $0.150(1.07)$ \\
$\mathrm{T}_{16}$ & $1.66(1.63)$ & $0.221(1.11)$ & $1.71(1.65)$ & $1.70(1.64)$ & $0.153(1.07)$ \\
$\mathrm{T}_{17}$ & $1.63(1.62)$ & $0.222(1.10)$ & $1.72(1.65)$ & $1.68(1.64)$ & $0.154(1.07)$ \\
$\mathrm{C} . \mathrm{D}_{(0.05)}$ & $\mathrm{NS}$ & $\mathrm{NS}$ & 0.02 & 0.02 & 0.003 \\
\hline
\end{tabular}

*Figures in the parentheses are transformed mean, NS: Non-significant.

\section{Effects of girdling and micro-nutrients on oil content of olive}

Application of $0.6 \%$ zinc sulphate in combination with $0.4 \%$ boric acid resulted in the highest oil content $((25.49 \%) \%)$ which was significantly higher compared to all other treatments during the year 2008 to 2009, whereas the minimum oil content (21.23\%) was extracted from fruits of untreated trees (Table 3). During the second year of investigation, application of $0.6 \%$ zinc sulphate in combination with $0.4 \%$ boric acid resulted in significantly higher oil content $(25.75 \%)$ as compared to all other treatments tried in this study while, it was minimum $(20.68 \%)$ in control. From the pooled data it is evident that the highest oil content (25.62\%) was obtained in fruits from trees sprayed with $0.6 \%$ zinc sulphate in combination with $0.4 \%$ boric acid, which was significantly higher than all other treatments. The minimum oil content of $20.96 \% \%$ was recovered from fruits of untreated trees. Overall improvement in fruit weight, size and pulp: stone ratio in the present study might be responsible for increased oil contents in olive fruit and the results obtained are in consonance with the findings of Jordao and Lietao (1990) who reported that there was a positive correlation between the fruit $\mathrm{Zn}$ concentration and the weight and oil content of the olive fruit.

\section{Effects of girdling and micro-nutrients on leaf $\mathrm{N}, \mathrm{P}, \mathrm{K}$, $\mathrm{Ca}$ and Mg content of olive}

In the present study, leaf nitrogen and phosphorus were not affected by girdling and foliar application of zinc sulphate and boric acid applied singly or in combination. However, leaf potassium, calcium and magnesium were increased as compared to untreated trees (Table 4). Foliar application of boric acid and zinc sulphate had significant effects on the concentration of nitrogen, phosphorus and potassium in leaves and fruits of olive cultivar Zard as reported by Taheri and Talaie (2001) and the results obtained in the present study are in line with their findings.

\section{Conclusion}

From this study it may be concluded that foliar application of zinc sulphate in combination with boric acid resulted in better growth, physical characteristics and oil content of olive fruits as compared to control and single application of zinc sulphate or boric acid. Application of $0.5 \%$ zinc sulphate in combination with $0.5 \%$ boric acid proved to be the best for improving the shoot extension growth, chlorophyll content of leaves, fruit size, weight and volume, pulp:stone ratio and oil content of olive cv. Frontoio.

\section{Conflict of Interests}

The author(s) have not declared any conflict of interests.

\section{REFERENCES}

Ahmad M, Kaul RK, Kaul BL (2005). Effect of girdling, thinning and $\mathrm{GA}_{3}$ 
on fruit growth, yield, quality and shelf life of grapes (Vitis vinifera L.) cv. Perlette. Acta Hort. 696:309-313.

AOAC (1980). Official methods of Analysis of the analytical chemists.

Association of official Agricultural Chemists, $13^{\text {th }}$ Edn., Washington, D.C. P1018.

Arnon DI (1949). Copper enzymes in isolated chloroplasts. Polyphenoloxidase in Beta vulgaris. Plant Physiol. 24:1-15.

Banik BC, Sen SK (1997). Effect of three level of iron, boron, zinc and their interactions on growth, flowering and yield of mango cv. Fazli. Hort. J. 10(1): 23-29.

Bybordi A, Malakouti MJ (2006). Effects of foliar applications of nitrogen, boron and zinc on fruit setting and quality of almonds. Acta Hort. 726:351-357.

Chanana YR, Gill KS (2006). Impact of girdling, thinning and their combination on quality and maturity in Florda Prince peach. Indian $\mathrm{J}$. Hort. 63(1):27-30.

Chapman HD (1964). Suggested foliar sampling and handling techniques for determining nutrient status of some field, horticultural and plantation crops. Indian J. Hort. 21:98-119.

Choi ST, Song WD, Park DS, Kang SM (2010). Effect of different girdling dates on tree growth, fruit characteristics and reserve accumulation in a late-maturing persimmon. Sci. Hort.126:152-155.

Dutta P (2004). Effect of foliar boron application on panicle growth, fruit retention and physico-chemical characters of mango cv. Himsagar. Indian J. Hort. 61(3):265-266.

FAO (2012). Statistical Year Book 2012. A Publication of Food and Agricultural Organization. Available at $h t t p: / /$ faostat3. fao.org /home lindex.html\#DOWNLOAD.

Hamdy IMI, Ahmed YM, Ahmed FF (2007). Relation of fruiting in Hindy Bisinara mangoes to foliar nutrition with $\mathrm{Mg}, \mathrm{B}$ and $\mathrm{Zn}$ and some antioxidants. In: $8^{\text {th }}$ African Crop Science Society Conference, ElMinia, Egypt. 27(31):411-415.

Jackson ML (1973). Soil Chemical Analysis. Prentice Hall of India Ltd., New Delhi, P. 498.

Jordao PV, Lietao F (1990). The olive mineral composition and some parameters of quality in fifty olive cultivars in Portugal. Acta Hort. 286:461-464.

Kenworthy AL (1964). Fruit, nut and plantation crops, deciduous and evergreen. A guide for collecting foliar samples for nutrient element analysis. Memo Horticultural Department Michigan State University, Michigan, pp. 223-224.
Keshavarz K, Vahdati K, Samar M, Azadegan B, Brown PH (2011). Foliar application of zinc and boron improves walnut vegetative and reproductive growth. Hort. Tech. 21(2):181-186.

Panse VG, Sukhame PV (2000). Statistical Methods for Agricultural Workers. Publication Information Division of ICAR, New Delhi.

Piper CS (1966). Soil and Plant Analysis. Hans Publishers, Bombay, India, pp. 40-51.

Proietti P, Tombesi A (1990). Effect of girdling on photosynthetic activity in olive leaves. Acta Hort. 286:215-218.

Rajaie M, Ejraie AK, Owliaie HR, Tavakoli AR (2009). Effect of zinc and boron interaction on growth and mineral composition of lemon seedlings in a calcareous soil. International J. Plant Prod. 3(1):39-50.

Ryugo K (1988). Fruit culture: It's Science and Art. John Wiley and Sons. pp. 259-261.

Sharma AK, Singh K, Mishra SP (2003). Effect of foliar spray of zinc sulphate, 2,4,5-T and $\mathrm{GA}_{3}$ on quality of kagzi lime (Citrus aurantifolia Swingle). The Orissa J. Hort. 31(2):29-32.

Singh VK, Bhriguvanshi SR, Chatterjee C (2009). Effect of micronutrients on growth and yield of mango (Mangifera indica L.) cv. Dashehari. Asian J. Hort. 4(1):112-115.

Taheri M, Talaie A (2001). The effect of chemical spray on the qualitative and quantitative characteristics of "Zard" olive fruits. Acta Hort. 564:343-348.

Tariq M, Sharif M, Shah Z, Khan R (2007). Effect of foliar application of micro-nutrients on the yield and quality of sweet orange (Citrus sinensis L.). Pak. J. Biol. Sci. 10(11):1823-1828.

Ungerer SF, Steyn WJ (2009). Effect of scoring and $\mathrm{GA}_{3}$ application during full bloom on fruit set and yield in 'Triumph' Persimmon. Acta Hort. 833:207-211.

Yadav S, Shukla HS, Ram RA (2010). Studies on foliar application of $\mathrm{NAA}, \mathrm{GA}_{3}$, boric acid, and $\mathrm{Ca}\left(\mathrm{NO}_{3}\right)_{2}$ on fruit retention, growth, yield and quality of aonla (Emblica officinalis Gaertn,) cv. Banarasi. Hort. J. 23(2):64-67. 